Article

\title{
Evaluation of Sustainable Development Management in EU Countries
}

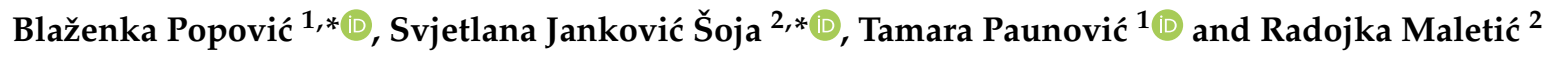 \\ 1 Department of Agribusiness Management, Faculty of Agriculture, University of Belgrade, Nemanjina 6, \\ 11000 Belgrade, Serbia; tamara@agrif.bg.ac.rs \\ 2 Department of Statistics, Faculty of Agriculture, University of Belgrade, Nemanjina 6, 11000 Belgrade, Serbia; \\ maletic@agrif.bg.ac.rs \\ * Correspondence: blazenka@agrif.bg.ac.rs (B.P.); svjetlanajs@agrif.bg.ac.rs (S.J.Š.); \\ Tel.: +381-63-474-890 (B.P.); +381-60-554-9604 (S.J.Š.)
}

Received: 1 November 2019; Accepted: 10 December 2019; Published: 13 December 2019

check for updates

\begin{abstract}
The term sustainable development is used in many areas and spheres of life and is becoming a modern phenomenon determining the direction of progress of every society. Sustainable development implies continuous economic development with respect to environmental principles and focuses on overcoming conflicts between economy and ecology. The aim of this paper is to evaluate sustainable development management in EU countries through selected indicators characterizing sustainable development and its core dimensions. We present the results of an evaluation of the sustainable development of EU countries using cluster analysis. Countries that are similar in terms of sustainability are identified by cluster analysis. Four clusters were separated, the affiliation of each country to a particular cluster was determined, and the characteristics of each cluster were defined. The goal of sustainability management is to create an adequate approach to development of the economic and environmental performance, and therefore achieve sustainability. The achievements of most developed countries should be an incentive for those that are at a lower level of development. In addition, this research provides insight into some specific goals of sustainable development where some countries are lagging behind. This could be the basis for directing efforts in specific areas of sustainable development to improve their own position in such an important global issue.
\end{abstract}

Keywords: sustainable development management; sustainable development goal (SDG) indicators; EU countries; cluster analysis

\section{Introduction}

Recently, sustainable development has become an exceptionally attractive topic, both in scientific research and in everyday life. Sustainable development is a way to create innovative economies that follow dynamic changes in the world and focus on the skills, needs, and expectations of people, as well as improving the position of women in public life, improving living and working conditions, and taking into account environmental protection so that future generations can meet their own needs [1]. Due to the constant progress of society, there is a threat of depleting scarce natural resources. For this reason, research on sustainable development can help to raise the awareness of individuals and, then, the community to understand the impact of their own decisions on a broader scale [2]. Therefore, inclusive development, which focuses on the social and environmental aspects of development [3], plays a significant role, in addition to sustainable development, in achieving high living standards and quality of life for all people [4]. Inclusive development involves the inclusion of marginalized people, sectors, and countries in social, political, and economic processes in order to increase human 
well-being along with social and environmental sustainability [3]. For this reason, national strategies should focus on both sustainable and inclusive development [4] to ensure a better future for all.

The goal of sustainable development is achieved through a dynamic process of improving the technical and technological work basis, the growth of social wealth, and quality of life without neglecting the need for environmental protection, as well as preserving resources for future generations. Sustainable development management involves the continuous monitoring of the intensity of economic, social, and environmental measures with the aim of finding a new type of healthier and long-term development. The basic elements of sustainable growth and development are the sustainable growth of GDP per capita, reduction of unemployment and poverty, productivity growth, reduction of income gap, social protection for all, while striking a balance between economic growth and environmental protection $[5,6]$. On the one hand, research on sustainable development provides meaningful information for decision makers to properly set priorities and initiate their actions [7], and on the other hand, such research may offer possible future scenarios [8]. A link between the scientific and non-scientific community must exist in order to achieve the flow of information, and thus create conditions for technology and knowledge exchange, with the aim of accelerating change at the local level [9], which should have a positive impact on achieving sustainable development globally. For the third decade, specifically since 1992, the United Nations has dealt with this issue, thereby increasing international cooperation in an effort to make the world a better place to live [8].

Tools for measuring the achievement of the Sustainable Development Goals are indicators that are constantly being improved, and thus enable better sustainable development management. The first set of 134 indicators (The Commission on Sustainable Development-CSD indicators) for the successful evaluation of measures and activities regarding the implementation of sustainable development strategies has been defined. Over time, the initial set of indicators have been upgraded and reduced to a set of 96 indicators [10]. The Commission on Sustainable Development, which is the main creator of these indicators, ceased to operate in September 2013 [11]. Since then, creation of a new set of indicators has been awaited by the United Nations.

As the authors of a previous study [12] which ranked EU-28 countries based on CSD indicators by the appropriate statistical method, it was interesting to us to use new indicators, i.e., sustainable development goal (SDG) indicators adopted on 6 July 2017 [13] in order to group the EU-28 countries.

The Sustainable Development Goals, 17 in all, are a framework for achieving a better, but also a sustainable future and managing the social, economic, and environmental dimensions of life [14,15]. SDGs are designed to be applicable to all nations, regardless of GDP level or geographical location [16]. They are interconnected and related to the global challenges we face on a daily basis such as poverty, inequality, climate, environmental degradation, peace and justice, sustainable consumption, and many more. SDGs can help government officials, businesses, and civil society to better understand key global challenges [17] and to manage these challenges. Each of the goals has a number of targets that specify the corresponding goal in more detail, and therefore provides a better understanding for achievement of the goal. The ultimate goal is to achieve each goal and target by 2030 [18]. Progress towards these targets is tracked by 232 defined indicators in total [19]. This research involves a significantly smaller number of indicators, more precisely 37 indicators, as data pertaining to all indicators and all countries for the observed 2016 year were not available.

The adoption of new SDG targets and indicators launched a series of new research on sustainable development. The definition of sustainable development and the wide range of goals and targets adopted enable researchers and scientists from various fields of interest to devote their research to this topic. For example, the authors of [17] presented a goal programming model for calculating the composite SDG index, which they applied to EU-28 Member States, thus providing insight into the relative position of the observed countries when it comes to achieving the Sustainable Development Goals. On the other hand, the authors of [1] have focused solely on one goal of sustainable development, goal nine, which refers to innovation as an important factor of economic growth, and therefore employment growth. The authors proposed a composite index, based on SDG 
indicators, that assesses the level of innovation of EU Member States and enables their comparative analysis. In [4], productive employment is linked to inclusive and sustainable development within EU countries during the recent economic crisis and recovery period. Results showed that the high level of inclusive and sustainable development can be explained by the high level of labor productivity, as well as the efficient employment structure by sectors, but also by the low level of precarious employment. The authors of [8] started from the fact that the implementation of SDGs, which have a global dimension, in different regions and countries, depends on the set priorities of the observed country, as well as on the main problems the nation is currently struggling with. For this reason, the authors, who are from different geographical regions, have considered and analyzed the link between SDGs and the underlying local problems and challenges of the region. Researchers in the field of social innovations [20], with the help of Sustainable Development Goals, proposed and implemented a categorization system for different social needs. One group of researchers [21] strongly criticized the approach and understanding of sustainable development by the EU bioeconomy policy, as they believe that such a way of understanding the concept of sustainability could have profound consequences when implementing the adopted policies. Namely, the authors believe that the EU bioeconomy policy gives primacy to the economic dimension as compared with the social and environmental dimension, which, according to them would lead to negative effects on biomass production. Such and similar research could be useful to compensate and correct any gaps in the sustainable development strategy in the future.

\section{Materials and Methods}

Choosing indicators to analyze the sustainable development of EU countries was not an easy task. For a better understanding of the indicators, we followed a United Nations document [13] presenting a report of the Sustainable Development Goals and Targets, as well as indicators to monitor the achievement of the set goals, adopted by the General Assembly held on 6 July 2017. These indicators were developed and presented by the Inter-Agency and Expert Group on SDG Indicators. Given the date of adoption of the Sustainable Development Indicators, it was clear that the analysis was based on the year preceding 2017. For the purpose of selecting the year for analyzing indicators, we prepared a database for the period from 2009 to 2018 for all indicators with available data from the following four commonly used data sources: the United Nations [22], the World Bank [23], Eurostat [24], and FAO [25] websites. These sources also represent the institutions that have been given the responsibility for developing the methodology and collecting data on some sustainable development indicators. For example, the World Bank is in charge of collecting data for 20 indicators but is also involved in the development and monitoring of an additional 22 indicators. The indicators cover a wider range of topics in which the World Bank has expertise, including poverty and inequality, social protection, gender equality, health, energy, infrastructure, etc. Responsibilities and duties for indicators by individual institutions can be found in the Tier classification document [26]. Sustainable development indicators are classified into the following three tiers: Tier 1 indicators are those with an established methodology and good data coverage, Tier 2 indicators have an established methodology but lack good data coverage, and Tier 3 indicators currently lack both methodology and data coverage. We chose to collect data only for indicators belonging to Tier $1[26,27]$. Out of 232 Sustainable Development Indicators, the tier classification contains 101 Tier 1 indicators. Although indicators belonging to this level should have good data coverage, the result of the data collected was disappointing. For a large number of Sustainable Development Goals, no data was available for any indicator, or data were available for only one indicator. For example, Goal 1, which refers to ending poverty in all its forms everywhere, with as many as 14 indicators proposed in the above-mentioned document, there were no data for any indicator for observed countries and for the reference period, or even for those Tier 1 indicators. For this reason, in order to cover the topic of poverty in some way, we decided to include a Eurostat indicator that had been monitored for years, referring to Goal 1, "people at risk of poverty or social exclusion (\% of total population)". In addition to Goal 1, five more goals were presented in 
this study only with one indicator. These were Goal 6, Goal 7, Goal 10, Goal 11, and Goal 14. The reason for this was the lack of data on indicators either for the selected 2016 year or for individual countries. Achieving the targets in Goal 6 which ensures availability and sustainable management of water and sanitation for all is monitored by 11 indicators, Goal 7 ensures access to affordable, reliable, sustainable, and modern energy for all is monitored by six indicators; Goal 10reduces inequality within and among countries is monitored by 11 indicators, Goal 11 aims to make cities and human settlements inclusive, safe, resilient, and sustainable is monitored by 15 indicators, and finally, Goal 14 conserves and sustainably uses the oceans, seas, and marine resources for sustainable development is monitored using 10 indicators [26]. For each goal mentioned, we were able to find only one indicator.

The research is based on 36 SDG indicators, and the GDP per capita indicator is also included. The reason for including this indicator in the analysis is explained later. The 2016 calendar year was selected for analysis considering that most of the indicators were available in that year for all EU Member States. Some indicators were replaced by similar indicators from different sources in order to include as many indicators as possible in the analysis. For this reason, the research included indicators "people at risk of poverty or social exclusion (\% of total population)" and "participation in early childhood education". For some goals, we were unable to find any indicators that were available for all observed countries. For example, Goal 12 refers to "ensure sustainable consumption and production patterns" and according to the Tier classification document [26] is described by 13 indicators, Goal 13 is related to combat climate changes and their impacts and is described by eight indicators, and Goal 16 promotes peaceful and inclusive societies for sustainable development, providing access to justice for all and building effective, accountable, and inclusive institutions at all levels and is described with as many as 23 indicators. The goals mentioned do not appear in Table 1, which covers all indicators included in this research. Table 1 also shows the download sources for each indicator, as data were collected from different sources, i.e., the United Nations [22], the World Bank [23], Eurostat [24], and FAO [25] websites.

Table 1. Indicators included in the research.

\begin{tabular}{|c|c|c|c|}
\hline Target & Target Description & Indicators & Source \\
\hline Goal 1 & End poverty in all its forms everywhere & $\begin{array}{l}\text { 1.1 People at risk of poverty or social exclusion (\% of } \\
\text { total population) }\end{array}$ & Eurostat \\
\hline Goal 3 & $\begin{array}{l}\text { Ensure healthy lives and promote } \\
\text { well-being for all at all ages }\end{array}$ & $\begin{array}{l}\text { 3.1 Under-five mortality rate, by sex (deaths per } 1000 \\
\text { live births) } \\
\text { 3.2 Neonatal mortality rate (deaths per } 1000 \text { live births) } \\
\text { 3.3 Tuberculosis incidence (per } 100,000 \text { population) } \\
\text { 3.4 Number of people requiring interventions against } \\
\text { neglected tropical diseases (number) } \\
\text { 3.5 Mortality rate attributed to cardiovascular disease, } \\
\text { cancer, diabetes or chronic respiratory disease } \\
\text { (probability) } \\
\text { 3.6 Suicide mortality rate, by sex (deaths per 100,000 } \\
\text { population) } \\
\text { 3.7 Age-standardized mortality rate attributed to } \\
\text { ambient air pollution (deaths per } 100,000 \text { population) } \\
\text { 3.8 Mortality rate attributed to unsafe water, unsafe } \\
\text { sanitation and lack of hygiene (deaths per 100,000 } \\
\text { population) } \\
\text { 3.9 Proportion of the target population with access to } 3 \\
\text { doses of diphtheria-tetanus-pertussis (DTP3) (\%) }\end{array}$ & United Nations \\
\hline
\end{tabular}


Table 1. Cont.

\begin{tabular}{|c|c|c|c|}
\hline Target & Target Description & Indicators & Source \\
\hline Goal 5 & $\begin{array}{l}\text { Achieve gender equality and empower all } \\
\text { women and girls }\end{array}$ & $\begin{array}{l}\text { 5.1 Proportion of seats held by women in national } \\
\text { parliaments ( } \% \text { of total number of seats) } \\
5.2 \text { Proportion of women in managerial positions (\%) }\end{array}$ & United Nations \\
\hline Goal 7 & $\begin{array}{l}\text { Ensure access to affordable, reliable, } \\
\text { sustainable and modern energy for all }\end{array}$ & $\begin{array}{l}\text { 7.1 Proportion of population with primary reliance on } \\
\text { clean fuels and technology }(\%)\end{array}$ & United Nations \\
\hline Goal 8 & $\begin{array}{l}\text { Promote sustained, inclusive and } \\
\text { sustainable economic growth, full and } \\
\text { productive employment and decent work } \\
\text { for all }\end{array}$ & $\begin{array}{l}\text { 8.1 GDP per capita growth (annual \%) } \\
\text { 8.2 Annual growth rate of real GDP per employed } \\
\text { person (\%) } \\
\text { 8.3 Domestic material consumption per unit of GDP, by } \\
\text { type of raw material (kilograms per constant } 2010 \\
\text { United States dollars) } \\
\text { 8.4 Unemployment, total (\% of total labor force) } \\
\text { (modeled ILO estimate) } \\
\text { 8.5 Share of youth not in education, employment or } \\
\text { training, total (\% of youth population) }\end{array}$ & $\begin{array}{l}\text { United Nations } \\
\text { the World Bank } \\
\text { the World Bank }\end{array}$ \\
\hline Goal 9 & $\begin{array}{l}\text { Build resilient infrastructure, promote } \\
\text { inclusive and sustainable industrialization } \\
\text { and foster innovation }\end{array}$ & $\begin{array}{l}\text { 9.1 Manufacturing, value added (\% of GDP) } \\
\text { 9.2 Manufacturing employment as a proportion of total } \\
\text { employment }(\%) \\
\text { 9.3 Research and development expenditure (\% of GDP) } \\
\text { 9.4 Carbon dioxide emissions per unit of GDP }\end{array}$ & $\begin{array}{l}\text { the World Bank } \\
\text { United Nations } \\
\text { the World Bank } \\
\text { United Nations }\end{array}$ \\
\hline Goal 10 & $\begin{array}{l}\text { Reduce inequality within and among } \\
\text { countries }\end{array}$ & 10.1 Foreign direct investment, net inflows ( $\%$ of GDP) & the World Bank \\
\hline Goal 15 & $\begin{array}{l}\text { Protect, restore and promote sustainable } \\
\text { use of terrestrial ecosystems, sustainably } \\
\text { manage forests, combat desertification, and } \\
\text { halt and reverse land degradation and halt } \\
\text { biodiversity loss }\end{array}$ & $\begin{array}{l}\text { 15.1 Average proportion of Terrestrial Key Biodiversity } \\
\text { Areas (KBAs) covered by protected areas (\%) } \\
\text { 15.2 Forest area certified under an independently } \\
\text { verified certification scheme (thousands of hectares) } \\
\text { 15.3 Red List Index }\end{array}$ & United Nations \\
\hline Goal 17 & $\begin{array}{l}\text { Strengthen the means of implementation } \\
\text { and revitalize the Global Partnership for } \\
\text { Sustainable Development }\end{array}$ & $\begin{array}{l}\text { 17.1 Volume of remittances (in United States dollars) as } \\
\text { a proportion of total GDP (\%) } \\
17.2 \text { Internet users per } 100 \text { inhabitants }\end{array}$ & the World Bank \\
\hline
\end{tabular}

When analyzing the sustainable development, we mainly chose to analyze a specific area, such as gas emission [28-31], energy [32-34], agriculture [35-39], health care systems [40-42], etc. The aim of this paper is to simultaneously capture all available economic, social, and environmental indicators of the sustainable development of EU countries in order to get comprehensive insight into each EU country and their similarities and differences. Given the large number of heterogeneous indicators included in the analysis and the low level of dependency between them, cluster analysis was used as the most appropriate method for grouping and identifying similarities of the observed countries.

Cluster analysis is a method designed to classify individual observation units based on their similarity which aims to form a number of very internally homogeneous groups of observation units. The grouping (clustering) of observation units is based on different characteristics (indicators), measured for each observation unit individually, and the starting point is the selection of an appropriate distance measure, since it is necessary to determine how "similar" or "different" they are to each other. There are a number of different distance measures and the most commonly used include: Euclidean distance, squared Euclidean distance, Mahalanobis distance, Minkowski distance, and Manhattan distance [43]. In this paper, the squared Euclidean distance is used as a distance measure, which is calculated using the following expression [44]: 


$$
d_{i j}^{2}=\sum_{k=1}^{p}\left(X_{i k}-X_{j k}\right)
$$

where $p$ is the number of indicators, $x i k$ is the value of the observation unit $x i$ for the indicator $X k$, and $x j k$ is the value of the observation unit $x j$ for the indicator $X k$. Using the selected distance measure and the starting ( $\mathrm{n} \times \mathrm{p}$ ) data matrix ( $\mathrm{n}$ objects classified based on $\mathrm{p}$ indicators), a distance matrix $(\mathrm{n} \times \mathrm{n})$ is formed and reflects the degree of similarity or difference between all pairs of objects that are grouped.

For the purposes of the analysis presented in this paper, an agglomerative hierarchical clustering analysis was implemented on selected indicators, based on the application of Ward's method [45]. One-way ANOVA was used to determine if there was a statistically significant difference between the separated clusters of the observed indicators. The analysis of the collected data and all necessary statistical calculations were carried out using the statistical software package for social sciences, SPSS version 17.0.

Table 2 presents the minimum and maximum values, as well as the average values and standard deviation of selected indicators.

Table 2. Descriptive statistical measures of selected indicators.

\begin{tabular}{|c|c|c|c|c|}
\hline Indicators & Min. & Max. & Mean & Std. Dev. \\
\hline People at risk of poverty or social exclusion $(\%)$ & 13.30 & 40.40 & 23.78 & 6.88 \\
\hline Proportion of local breeds classified as known being at risk (\%) & 0.00 & 99.12 & 56.81 & 30.34 \\
\hline Proportion of local breeds classified as known being not at risk $(\%)$ & 0.00 & 34.00 & 8.21 & 8.79 \\
\hline $\begin{array}{c}\text { Proportion of local breeds classified as being at unknown level of } \\
\text { risk of extinction }(\%)\end{array}$ & 0.00 & 100.00 & 34.98 & 33.36 \\
\hline Under-five mortality rate, by sex (deaths per 1000 live births) & 2.30 & 8.50 & 4.23 & 1.51 \\
\hline Neonatal mortality rate (deaths per 1000 live births) & 1.20 & 4.50 & 2.41 & 0.79 \\
\hline Tuberculosis incidence (per 100,000 population) & 3.70 & 64.00 & 12.34 & 13.72 \\
\hline $\begin{array}{c}\text { Number of people requiring interventions against neglected } \\
\text { tropical diseases (number) }\end{array}$ & 0.00 & 272.00 & 31.14 & 55.68 \\
\hline $\begin{array}{l}\text { Mortality rate attributed to cardiovascular disease. cancer. } \\
\text { diabetes or chronic respiratory disease (probability) }\end{array}$ & 9.10 & 23.60 & 13.98 & 4.61 \\
\hline Suicide mortality rate, by sex (deaths per 100,000 population) & 5.00 & 31.90 & 14.12 & 5.54 \\
\hline $\begin{array}{l}\text { Age-standardized mortality rate attributed to ambient air } \\
\text { pollution (deaths per } 100,000 \text { population) }\end{array}$ & 7.00 & 53.00 & 21.25 & 11.81 \\
\hline $\begin{array}{l}\text { Mortality rate attributed to unsafe water, unsafe sanitation and } \\
\text { lack of hygiene (deaths per } 100,000 \text { population) }\end{array}$ & 0.00 & 0.60 & 0.15 & 0.15 \\
\hline $\begin{array}{c}\text { Proportion of the target population with access to } 3 \text { doses of } \\
\text { diphtheria-tetanus-pertussis (DTP3) (\%) }\end{array}$ & 87.00 & 99.00 & 95.25 & 3.00 \\
\hline $\begin{array}{l}\text { Proportion of youth and adults with information and } \\
\text { communications technology (ICT) skills (\%) }\end{array}$ & 38.50 & 78.60 & 57.81 & 9.51 \\
\hline Participation in early childhood education & 75.10 & 100.00 & 92.54 & 6.61 \\
\hline $\begin{array}{c}\text { Proportion of seats held by women in national parliaments (\% of } \\
\text { total number of seats) }\end{array}$ & 10.10 & 43.55 & 26.59 & 10.08 \\
\hline Proportion of women in managerial positions (\%) & 17.74 & 47.25 & 32.99 & 6.31 \\
\hline Water body extent (permanent) (\% of total land area) & 0.14 & 9.91 & 1.96 & 2.43 \\
\hline $\begin{array}{l}\text { Proportion of population with primary reliance on clean fuels and } \\
\text { technology } \%)\end{array}$ & 86.00 & 95.00 & 94.29 & 2.03 \\
\hline GDP per capita (in United States dollars) & 8311.93 & $107,865.27$ & $35,144.33$ & $22,244.17$ \\
\hline GDP per capita growth (annual \%) & 0.36 & 5.40 & 2.41 & 1.28 \\
\hline Annual growth rate of real GDP per employed person $(\%)$ & -1.80 & 5.60 & 1.13 & 1.78 \\
\hline $\begin{array}{l}\text { Domestic material consumption per unit of GDP, by type of raw } \\
\text { material (kilograms per constant } 2010 \text { United States dollars) }\end{array}$ & 0.58 & 6.95 & 1.92 & 1.58 \\
\hline $\begin{array}{c}\text { Unemployment, total (\% of total labor force) (modeled ILO } \\
\text { estimate) }\end{array}$ & 3.95 & 23.54 & 8.65 & 4.45 \\
\hline $\begin{array}{c}\text { Share of youth not in education, employment or training, total ( } \% \\
\text { of youth population) }\end{array}$ & 4.57 & 19.54 & 10.99 & 4.11 \\
\hline Manufacturing, value added (\% of GDP) & 4.57 & 32.14 & 14.69 & 5.90 \\
\hline $\begin{array}{c}\text { Manufacturing employment as a proportion of total employment } \\
(\%)\end{array}$ & 4.24 & 27.80 & 15.33 & 5.63 \\
\hline Research and development expenditure (\% of GDP) & 0.44 & 3.25 & 1.53 & 0.86 \\
\hline
\end{tabular}


Table 2. Cont.

\begin{tabular}{|c|c|c|c|c|}
\hline Indicators & Min. & Max. & Mean & Std. Dev. \\
\hline Carbon dioxide emissions per unit of GDP & 0.08 & 0.47 & 0.20 & 0.08 \\
\hline Foreign direct investment, net inflows (\% of GDP) & -7.39 & 76.96 & 10.99 & 18.46 \\
\hline Terrestrial and marine protected areas ( $\%$ of total territorial area) & 1.69 & 55.09 & 21.31 & 11.77 \\
\hline $\begin{array}{c}\text { Average proportion of Terrestrial Key Biodiversity Areas (KBAs) } \\
\text { covered by protected areas (\%) }\end{array}$ & 56.26 & 99.40 & 81.24 & 11.85 \\
\hline Red List Index & 0.79 & 0.99 & 0.94 & 0.05 \\
\hline $\begin{array}{l}\text { Volume of remittances (in United States dollars) as a proportion of } \\
\text { total GDP }(\%)\end{array}$ & 0.17 & 4.45 & 1.52 & 1.33 \\
\hline Internet users per 100 inhabitants & 59.50 & 98.10 & 80.06 & 10.43 \\
\hline
\end{tabular}

Source: Authors' own work.

Before the concrete implementation of cluster analysis, it is necessary to pay attention to the measurement unit used to express the selected indicators. Namely, since the application of cluster analysis is based on calculating the values of the appropriate distance measures, it is important to note that most distance measures are quite sensitive to the presence of different measurement units. In order to eliminate the influence of different measurement units, and to keep all the indicators in the same position when calculating the distance measure, the $\mathrm{z}$-standardization procedure was carried out, that is, the transformation of the indicator values, $\mathrm{Xk}$ (for $k=1, \ldots, \mathrm{p}, \mathrm{p}=37$ ), into a standardized normally distributed variable, $\mathrm{Zk}$, with arithmetic mean 0 and standard deviation 1 , symbolically $[\mathrm{Xk} \rightarrow \mathrm{Zk}: \mathrm{N}(0 ; 1)]$, using the following expression:

$$
Z_{i k}=\frac{X_{i k}-\bar{X}_{k}}{S_{k}}
$$

for $\mathrm{k}=1, \ldots, \mathrm{p}, \mathrm{p}=37$ and $\mathrm{i}=1, \ldots, \mathrm{n}, \mathrm{n}=28$.

Where $\bar{X}$ is the arithmetic mean of the observed indicators, $S$ is the standard deviation of the observed indicators, and $\mathrm{n}$ is the total number of observed countries.

\section{Results and Discussion}

Cluster analysis was applied to standardized values of observed indicators, using Ward's method and the squared Euclidean distance as distance measures between observation units (i.e., observed states).

Selection of the optimal number of groups was made based on diagram values of the distance measure between the groups, as well as based on the dendrogram. A graphical representation of the squared Euclidean distance between countries (and/or formed groups of countries) is presented in Figure 1. Most often, the criterion for selecting the optimal number of groups is the moment when there is a sudden jump of the distance measure value, and therefore it may be concluded that the optimal number of groups was formed in step 24, i.e., at the moment the four groups of countries are separated, since this is followed by the interconnection of distinctly heterogeneous groups, as evidenced by the high value of the squared Euclidean distance. 


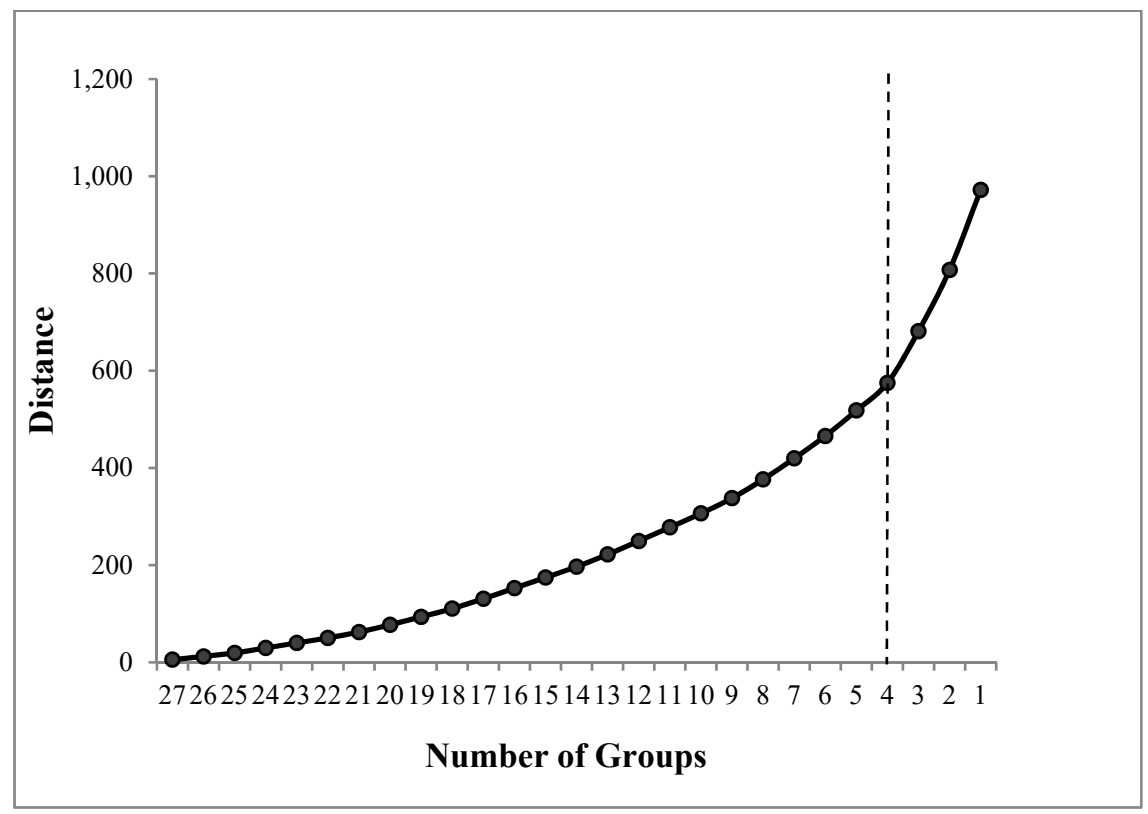

Figure 1. Graphical representation of values of the distance measure between the groups. Source, authors' own work.

Visual interpretation of the procedure and the results of hierarchical agglomeration for the observed EU countries is also presented in the form of the dendrogram in Figure 2.

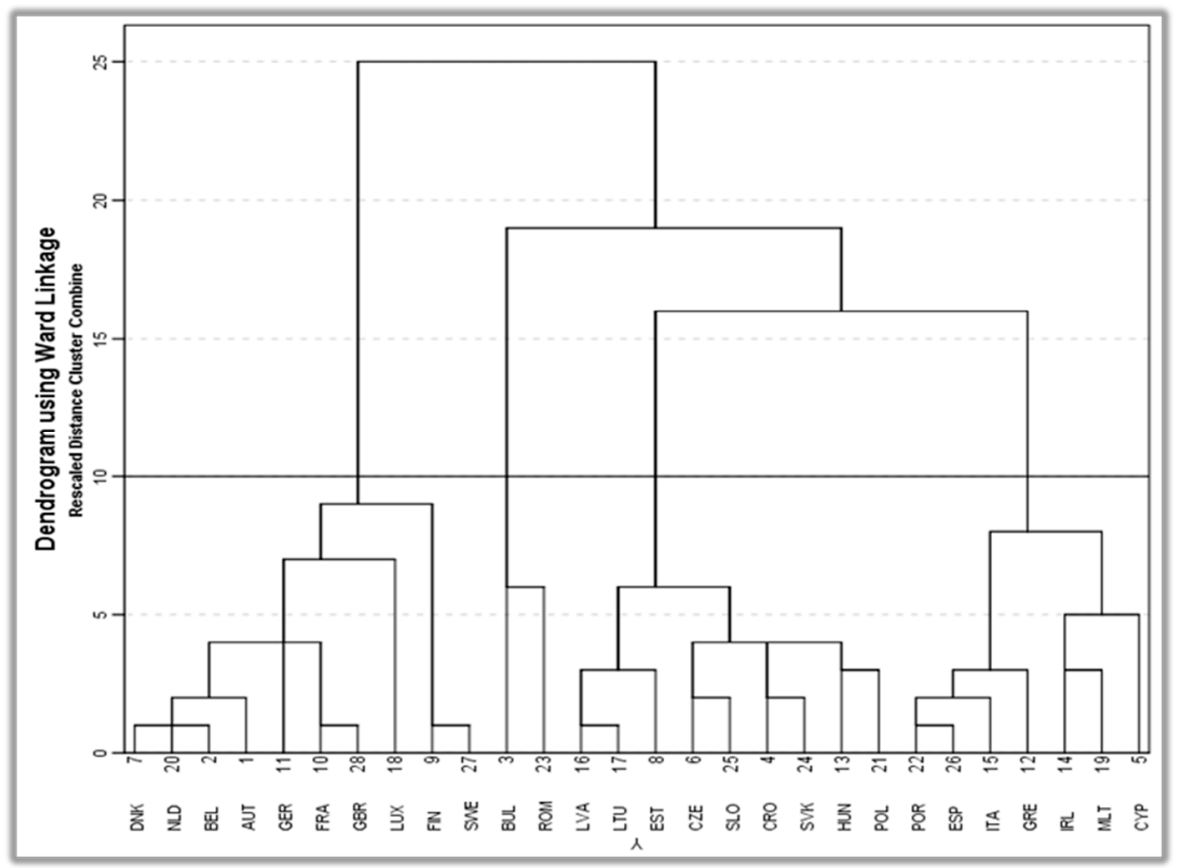

Figure 2. Dendrogram: Results of cluster analysis of $28 \mathrm{EU}$ countries according to Standardized Values of Selected Indicators, for the Year 2016. Source, authors' own work.

For clarity, the following abbreviations are used in Figure 2 in regards to EU Member States (EU-28):United Kingdom [GBR], Ireland [IRL], Belgium [BEL], Luxembourg [LUX], Netherlands [NLD], France [FRA], Portugal [POR], Spain [ESP], Sweden [SWE], Finland [FIN], Estonia [EST], Latvia [LVA], Lithuania [LTU], Denmark [DNK], Germany [GER], Austria [AUT], Italy [ITA], Poland [POL], Czech Republic [CZE], Slovak Republic [SVK], Malta [MLT], Cyprus [CYP], Hungary [HUN], Romania [ROM], Bulgaria [BUL], Greece [GRE], Slovenia [SLO], and Croatia [CRO]). 
On the basis of the results of the cluster analysis (Figure 2), it can be said that the EU countries do not form a homogeneous group in terms of sustainable development and achieving sustainability, with four groups being separated. The list of countries by identified groups is presented in Table 3 . The first cluster is the largest and is made up of the 10 most economically developed EU countries which are Austria, Belgium, Denmark, Finland, France, Germany, Netherlands, Luxembourg, Sweden and United Kingdom. The second cluster is the smallest and consists of only two countries, Bulgaria and Romania.

Table 3. Countries included in each cluster.

\begin{tabular}{cccc}
\hline Cluster I & Cluster II & Cluster III & Cluster IV \\
\hline Austria & Bulgaria & Latvia & Cyprus \\
Belgium & Romania & Lithuania & Greece \\
Denmark & & Estonia & Ireland \\
Finland & & Croatia & Italy \\
France & & Czech Republic & Malta \\
Germany & & Slovak Republic & Portugal \\
Netherlands & Slovenia & Spain \\
Luxembourg & Hungary & \\
Sweden & & Poland & \\
United Kingdom & & & \\
\hline
\end{tabular}

Source: Authors' own work.

The third cluster consists of the following nine countries: three Baltic countries (Latvia, Lithuania, and Estonia), four countries of Central Europe (Czech Republic, Slovak Republic, Hungary, and Poland) and two Balkan countries (Slovenia and Croatia). Ireland and the six countries of Southern Europe (Spain, Portugal, Malta, Italy, Greece, and Cyprus) form the fourth cluster.

Separated clusters also indicate the regional distribution of EU countries according to the realized sustainable development indicators (Figure 3).

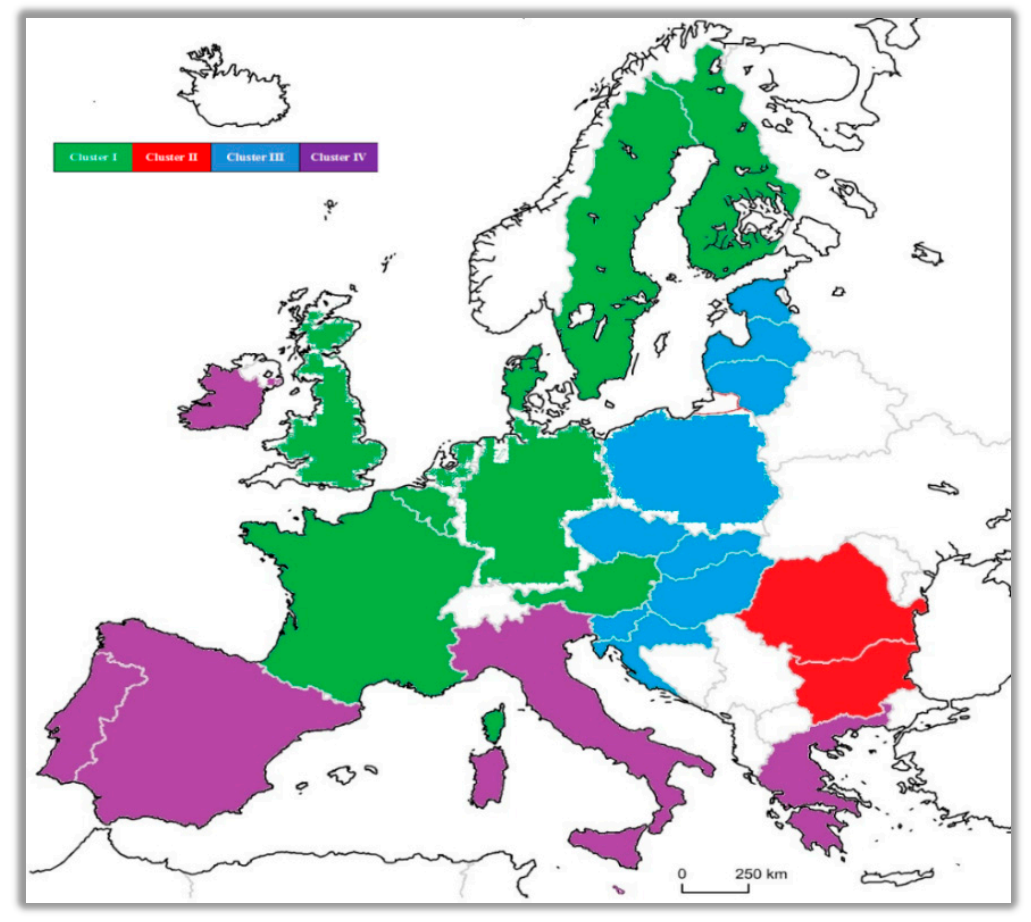

Figure 3. Countries according to cluster affiliation. 
At this point, it is interesting to return to our previous research [12] to look at changes from 2013 (the observed year of EU countries in the previous research) to 2016 (the observed year in this research). At first, it seems that a comparison is not possible because the aforementioned studies have used different statistical methods for data analysis, as well as different sets of sustainable development indicators. However, the results are quite similar and in the observed period there were no significant changes in the position of countries when it comes to achieving the Sustainable Development Goals. The study [12] includes EU-28 countries ranked according to the achieved objectives of the sustainable development, and the first 12 countries are in the first cluster in which the most economically developed countries stood out. The exceptions are Slovenia and the Czech Republic, which belong to the third cluster, together with countries whose ranks are from 18 to 26 . The fourth cluster consists of countries with ranges from 13 to 17 , and finally, the two lowest ranking countries form a separate, second cluster. The results may not be surprising given the substance of the clustering process, i.e., grouping objects (countries according to similarities of the observed indicators).

The average values of analyzed sustainable development indicators per cluster, as well as cluster rankings by indicators, are shown in Table 4.

All ten countries included in the first cluster are old EU Member States with a high level of economic, human, and inclusive development. The results of the analysis confirm the previous finding, since in most indicators this cluster is ranked first or second (Table 4). The best results have been achieved in the field of health care, investing most in research and development, information technology, as well as environmental protection. The exception is the GDP per capita growth indicator (annual \%) where the first cluster is ranked fourth. Accordingly, it can be concluded that the GDP of the most developed and most stable economies in the world is growing at a lower rate than the GDP of underdeveloped and developing countries. On the one hand, a very important factor for this is that the developed world has reached an enviable level of development (or GDP), and therefore the statistical basis for calculating the growth rate is very high. The growth rate is, in fact, nothing more than a change in GDP, expressed as a percentage as compared with the baseline (2015 level, if 2016 is analyzed). On the other hand, less developed and underdeveloped economies start from a low base (low level of GDP in 2015), and even a relatively small increase (GDP) seems large in percentage terms. It is, therefore, a statistical "deception". Although the GDP of developed countries is increasing more in absolute amount, it seems smaller in percentage amount, while in the case of undeveloped countries (Romania and Bulgaria, the second cluster) a smaller increase in GDP when expressed as a percentage (via growth rate) seems to be large. Due to this kind of statistical "deception", in order to get a more realistic picture regarding the GDP level, we included another indicator in the research that does not belong to the SDG indicator list. It is a GDP per capita indicator. The low ranking of the first cluster is also recorded in several indicators (mortality rate attributed to unsafe water, unsafe sanitation, and lack of hygiene deaths per 100,000 population); average proportion of Terrestrial Key Biodiversity Areas (KBAs) covered by protected areas (\%), but further analysis found that the differences between the clusters for these indicators were not statistically significant (Table 5). Among the countries belonging to the first cluster, the leading positions belong to Luxembourg and the Scandinavian countries. Similar results were obtained by Janković Šoja et al. [12], Guijarro and Poyatos [17], and Radojičić et al. [46]. The economies of these countries are characterized by flexible and modernized economic systems with high GDP per capita, leading to higher living standards, low unemployment, and relatively small differences between social classes [47]. In addition, Luxembourg's position can be explained by the fact that it is a country which has been able to continually develop and improve its generous and wide-ranging social protection regime over the past 100 years [48]. The results of this study are in line with the research of other authors who highlight the importance of GDP per capita, which is the driving force of socioeconomic and sustainable development $[49,50]$. 
Table 4. Average aariables per cluster.

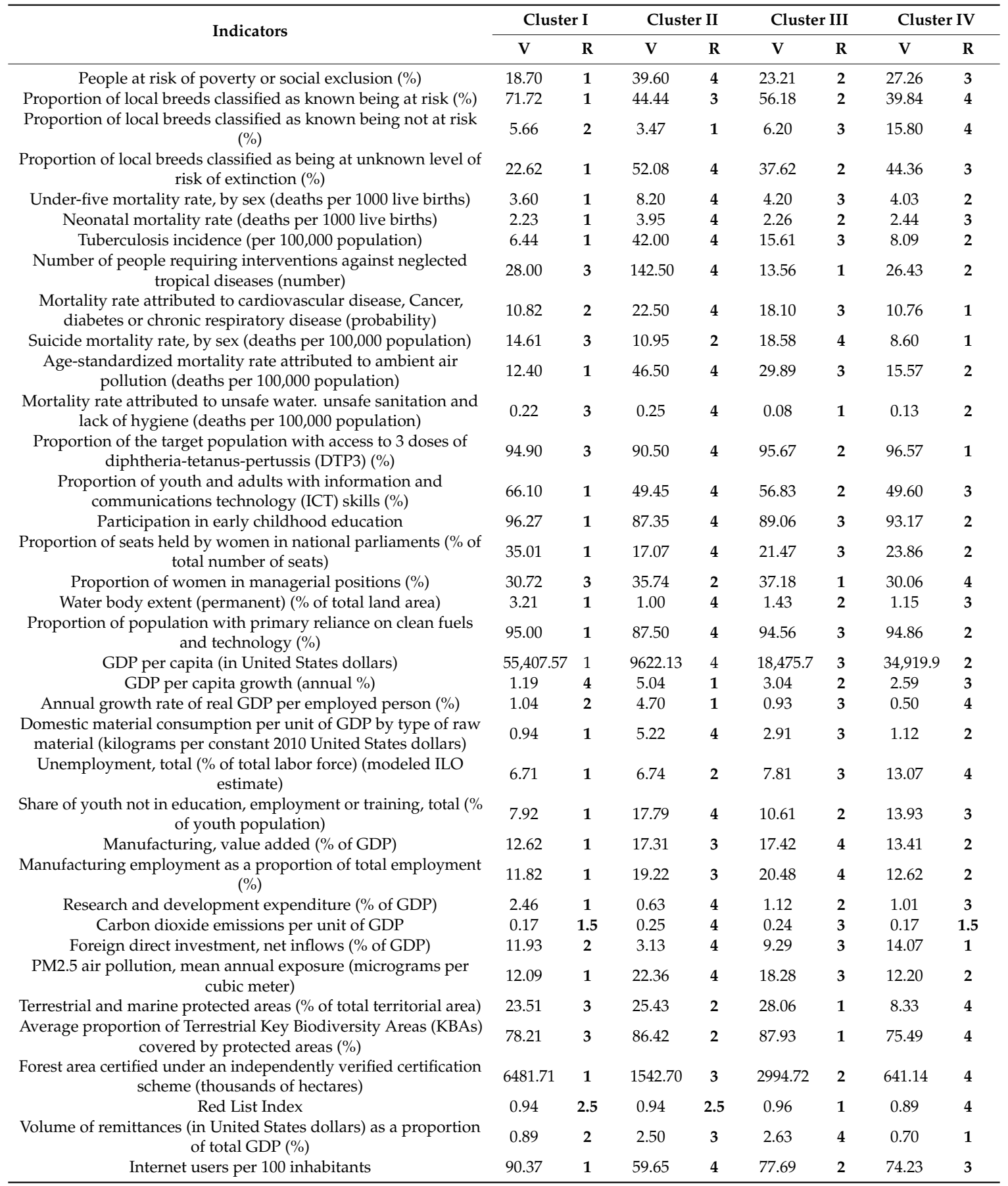

V, value and R, rank. Source: Authors' own work.

Romania and Bulgaria are grouped into the second cluster, which is the last ranked cluster in terms of achieved values of observed indicators (Table 4). This cluster is characterized by the lowest results achieved in terms of public health. The share of the population at risk of poverty is $66.53 \%$, which is higher in this cluster than the EU average. Advances in information technology and environmental protection are also at the lowest level. These are the countries least successful in achieving their sustainable development goals. As the poorest EU countries, they are significantly behind in achieving the EU vision for a sustainable European development based on balanced economic growth and price 
stability, a highly competitive social market economy aiming at full employment and social progress, as well as a high level of protection and environmental quality improvements.

Table 5. Results of the ANOVA.

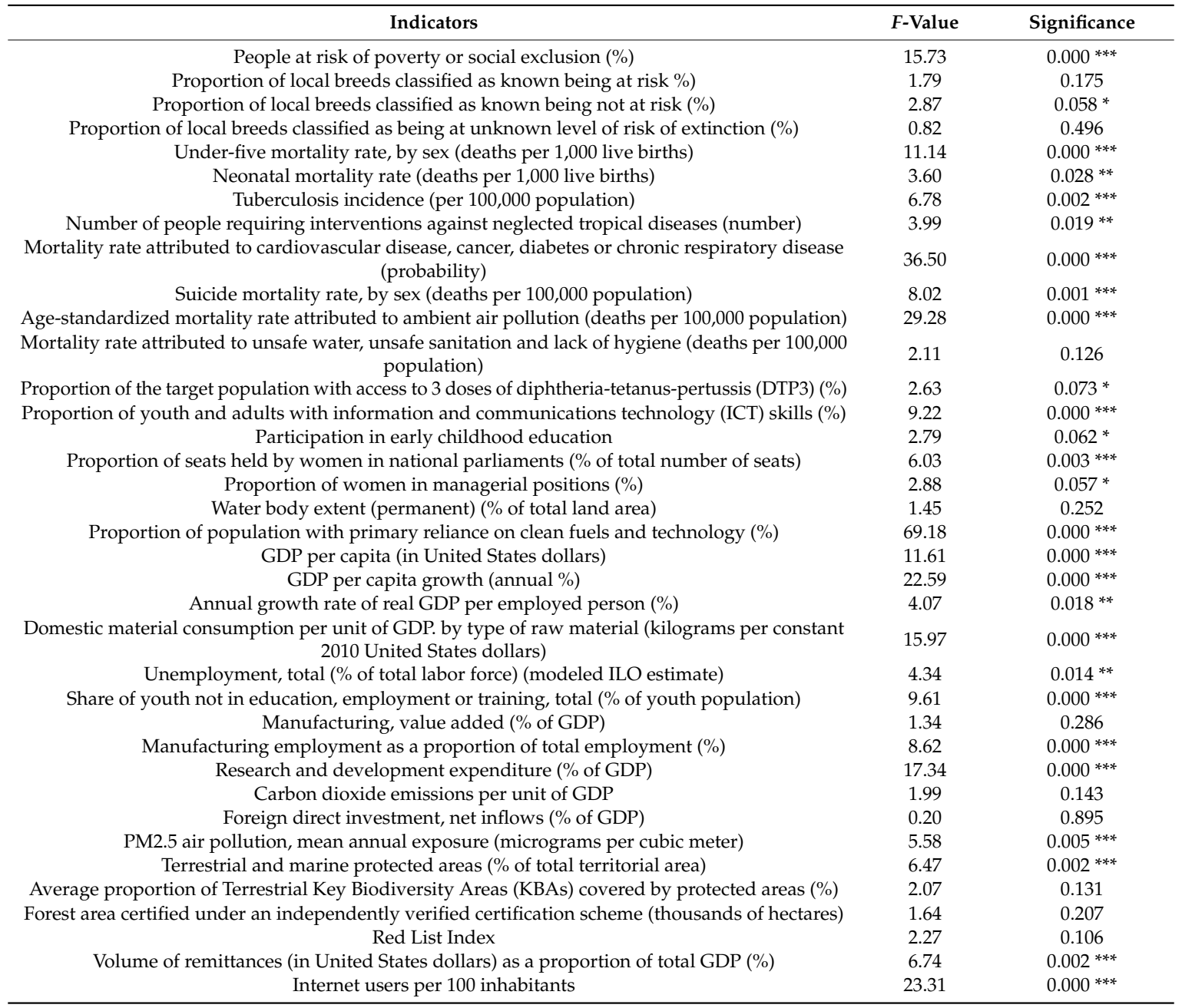

* Significant on $90 \%$ level, ${ }^{* *}$ significant on $95 \%$ level, and ${ }^{* * *}$ significant on $99 \%$ level. Source: Authors' own work.

The third cluster (consisting of nine countries, Table 3) was ranked second and third for most indicators, and unlike the fourth cluster which achieved similar results, had a higher number of indicators ranked first (terrestrial and marine protected areas, proportion of women in managerial positions, manufacturing value added, etc.) which qualifies it for second place according to the results in achieving sustainable development. Within this cluster, two groups of countries are identified (Figure 2). The Baltic countries are the first group, which differ from other countries of this cluster (the second group) by a higher percentage of the population at risk of poverty, better results in environmental protection, and better information technology achievements.

The fourth cluster, made up of Southern European countries (with the exception of Ireland), is generally ranked second and third, but different from the third cluster, it has several indicators (terrestrial and marine protected areas, proportion of women in managerial positions, unemployment total, etc.) with the lowest results, and therefore this cluster in ranked third in terms of achieved results. Within this cluster, two groups of countries are also identified (Figure 2). Interestingly, within this cluster, the so-called PIGS countries (Portugal, Italy, Greece, and Spain) have joined together [51], which differ from the other countries belonging to this cluster (Cyprus, Ireland. and Malta) by a 
higher percentage of the population at risk of poverty, higher unemployment, and lower GDP growth per employee.

Table 5 presents the results of the one-way ANOVA, which determined whether the clusters were statistically significantly different among each other according to the observed indicators of sustainable development. The results show that clusters differ in most indicators, and in a small number of indicators (ten indicators) these differences are not significant. Therefore, given that the differences between the clusters are statistically significant for the 27 indicators, we can say that the clusters differ strongly in the results related to achieving sustainable development.

\section{Conclusions}

Using the Ward method, EU countries are grouped, based on 37 indicators, into four relatively homogeneous groups. The first group (cluster 1) is made up of highly developed European countries, which have been singled out as a homogeneous group with the best track record of sustainable development indicators (health care, investing most in research and development, information technology, as well as environmental protection). The two poorest EU countries, Romania and Bulgaria, are grouped in the second cluster, which is the last ranked cluster, lagging behind in economic, social, and environmental indicators of sustainable development. The countries of Central Europe form the third cluster and the fourth cluster includes the countries of Southern Europe and Ireland. Central European Member States are better positioned than Southern European countries, characterized by a higher percentage of the population at risk of poverty, higher unemployment, lower GDP growth per employee, as well as poor performance in the IT sector and environmental protection.

On the basis of the results of the similarity assessment, it is possible to point out the lagging countries, as well as how to achieve better results and progress regarding sustainable development by following the example of those most developed. Sustainable development management is focused on finding and implementing activities, but also on the use of tools aimed to ensure sustainable development. Not all the tools of other economies are suitable to be used in all countries; however, it is possible to selectively determine and implement some of these tools in the management of sustainable development [52]. According to the research findings, decision makers could target specific policies of each of the regional clusters at the European level. These targeted policies could lead to progress in less developed regions in order to achieve a sustainable balance between economic growth, social, and environmental protection in the EU.

Achieving national development sustainability for countries belonging to the second cluster implies accelerating economic growth and development, reducing poverty, improving health care, ensuring effective pollution control and sustainable management of natural resources, improving the management system, and public participation while building capacity at all levels. In addition to the necessary accelerated economic development, the recommendation for the third cluster countries is to reduce pollution and invest more in education and health systems. The countries belonging to the fourth cluster should focus on reducing poverty and unemployment, as well as increasing the level of protection of natural resources. In order to ensure the sustainable development of a society, a holistic approach to managing complex social processes is required, as well as careful balancing of economical and social goals related to environmental protection and natural resources. Achieving the sustainability of national development requires a strategic approach, which is a long-term process and integrates different development processes, overcoming the conflict between the paradigm of economics and ecology.

Cluster analysis has proven to be a very useful and applicable method. The main benefit of this approach is that, for each EU country, a large number of sustainable development indicators can be simultaneously included in the analysis in order to form a homogeneous group of countries. However, it can be expected that a different choice of sustainable indicators could potentially lead to a different grouping of countries. Finding a new set of indicators could be a new study that builds on the current one and would allow a comparison of possible differences between different sets of indicators. In any 
case, it is necessary to elaborate further on this issue and potentially create a framework for assessing sustainable development.

Author Contributions: Conceptualization, B.P. and S.J.Š.; methodology, B.P.; validation, R.M.; formal analysis, B.P.; investigation, B.P. and S.J.̌̌s; resources, B.P. and S.J.Š.; data curation, S.J.Š.; writing—original draft preparation, B.P. and S.J.Š.; writing—review and editing, B.P. and S.J.Š.; visualization, T.P.; supervision, R.M.; project administration, T.P.; funding acquisition, R.M. and T.P.

Funding: This research received no external funding.

Acknowledgments: This work was supported by the Ministry of Science and Technological Development, "Development and application of new and traditional technologies in the production of competitive food products with added value for domestic and world markets—create wealth from the wealth of Serbia" under project number III 46001; and "Rural labour market and rural economy of Serbia-income diversification as a toll to overcome rural poverty" under project number OI 179028.

Conflicts of Interest: The authors declare no conflict of interest.

\section{References}

1. Szopik-Depczyńska, K.; Kędzierska-Szczepaniak, A.; Szczepaniak, K.; Cheba, K.; Gajda, W.; Ioppolo, G. Innovation in sustainable development: An investigation of the EU context using 2030 agenda indicators. Land Use Policy 2018, 79, 251-262. [CrossRef]

2. Leal Filho, W.; Azeiteiro, U.; Alves, F.; Pace, P.; Mifsud, M.; Brandli, L.; Caeiro, S.S.; Disterheft, A. Reinvigorating the sustainable development research agenda: The role of the sustainable development goals (SDG). Int. J. Sustain. Dev. World Ecol. 2018, 25, 1-12. [CrossRef]

3. Gupta, J.; Pouw, N.R.M.; Ros-Tonen, M.A.F. Towards an elaborated theory of inclusive development. Eur. J. Dev. Res. 2015, 27, 541-559. [CrossRef]

4. Georgescu, M.A.; Herman, E. Productive Employment for Inclusive and Sustainable Development in European Union Countries: A Multivariate Analysis. Sustainability 2019, 11, 1771. [CrossRef]

5. Schmid, G. Inclusive Growth: What Future for the European Social Model; IZA Policy Paper No. 82; Institute for the Study of Labor (IZA): Bonn, Germany, 2014. Available online: http://ftp.iza.org/pp82.pdf (accessed on 20 May 2018).

6. Islam, R.; Islam, I. Employment and Inclusive Development; Routledge: London, UK, 2015; ISBN 978041582596.

7. International Council for Science. A Guide to SDG Interactions: From Science to Implementation; ICSU: Paris, France, 2017. Available online: https://council.science/cms/2017/05/SDGs-Guide-to-Interactions.pdf. (accessed on 28 July 2019).

8. Lange Salvia, A.; Leal Filho, W.; Londero Brandli, L.; Sapper Griebeler, J. Assessing research trends related to Sustainable Development Goals: Local and global issues. J. Clean. Prod. 2019, 208, 841-849. [CrossRef]

9. Dlouhá, J.; Henderson, L.; Kapitulčinová, D.; Mader, C. Sustainability-oriented higher education networks: Characteristics and achievements in the context of the UN DESD. J. Clean. Prod. 2018, 172, 4263-4276. [CrossRef]

10. Department of Economic and Social Affairs. Indicators of Sustainable Development: Guidelines and Methodologies, 3rd ed.; United Nations: New York, NY, USA, 2007. Available online: https://sustainabledevelopment.un. org/content/documents/guidelines.pdf (accessed on 1 July 2019).

11. United Nations. Resolution adopted by the General Assembly on 21 December 2012-Implementation of Agenda 21, the Programme for the Further Implementation of Agenda 21 and the outcomes of the World Summit on Sustainable Development and of the United Nations Conference on Sustainable Development. 27 February 2013. Available online: https://www.un.org/ga/search/view_doc.asp?symbol=A/RES/67/203\& Lang $=\mathrm{E}$ (accessed on 17 June 2019).

12. Janković Šoja, S.; Anokić, A.; Bucalo Jelić, D.; Maletić, R. Ranking EU Countries According to Their Level of Success in Achieving the Objectives of the Sustainable Development Strategy. Sustainability 2016, 8, 306. [CrossRef]

13. United Nations. Resolution Adopted by the General Assembly on 6 July 2017. Available online: https: //undocs.org/A/RES/71/313 (accessed on 16 July 2019). 
14. Dlouhá, J.; Pospíšilová, M. Education for Sustainable Development Goals in public debate: The importance of participatory research in reflecting and supporting the consultation process in developing a vision for Czech education. J. Clean. Prod. 2018, 172, 4314-4327. [CrossRef]

15. Gupta, J.; Vegelin, C. Sustainable development goals and inclusive development. Int. Environ. Agreem. Polit. Law Econ. 2016, 16, 433-448. [CrossRef]

16. Burford, G.; Tamás, P.; Harder, M.K. Can we improve indicator design for complex sustainable development goals? A Comparison of a Values-Based and Conventional Approach. Sustainability 2016, 8, 861. [CrossRef]

17. Guijarro, F.; Poyatos, J.A. Designing a Sustainable Development Goal Index through a Goal Programming Model: The Case of EU-28 Countries. Sustainability 2018, 10, 3167. [CrossRef]

18. United Nations. Sustainable Development Goals. Available online: https://www.un.org/sustainabledevelopment/ sustainable-development-goals/ (accessed on 20 April 2019).

19. United Nations, Department of of Economic and Social Affairs. Global Indicator Framework for the Sustainable Development Goals and Targets of the 2030 Agenda for Sustainable Development. Available online: https:/unstats.un.org/sdgs/indicators/Global\%20Indicator\%20Framework\%20after\% 202019\%20refinement_Eng.pdf (accessed on 25 April 2019).

20. Eichler, G.M.; Schwarz, E.J. What Sustainable Developments Goals Do Social Innovations Address? A Systematic Review and Content Analysis of Social Innovation Literature. Sustainability 2019, 11, 522. [CrossRef]

21. Ramcilovic-Souminen, S.; Pülzl, H. Sustainable development-A 'selling point' of the emerging EU bioeconomy policy framework? J. Clean. Prod. 2018, 172, 4170-4180. [CrossRef]

22. United Nations. Database. Available online: https://unstats.un.org/sdgs/indicators/database/ (accessed on 8 March 2019).

23. World Bank Data. Database. Available online: https://data.worldbank.org/ (accessed on 23 March 2019).

24. Eurostat. Database. Available online: https://ec.europa.eu/eurostat/data/database (accessed on 24 March 2019).

25. Food and Agriculture Organization of the United Nations. Database. Available online: http://www.fao.org/ faostat/en/\#data (accessed on 24 March 2019).

26. United Nations. Tier Classification for Global SDG Indicators 31 December 2018. Available online: https://unstats.un.org/sdgs/files/Tier\%20Classification\%20of\%20SDG\%20Indicators_31\%20December\% 202018_web.pdf (accessed on 5 March 2019).

27. The World Bank. WDI and the Sustainable Development Goals. Available online: http://datatopics. worldbank.org/world-development-indicators/wdi-and-the-sustainable-development-goals.html (accessed on 5 March 2019).

28. Chen, R.; Yin, P.; Meng, X.; Liu, C.; Wang, L.; Xu, X.; Ross, J.A.; Tse, L.A.; Kan, H.; Zhou, M. Fine particulate air pollution and daily mortality: A nationwide analysis in 272 Chinese cities. Am. J. Respir. Crit. Care Med. 2017, 196, 73-81. [CrossRef] [PubMed]

29. Anderson, N.; Strader, R.; Davidson, C. Airborne reduced nitrogen: Ammonia emissions from agriculture and other sources. Environ. Int. 2003, 29, 277-286. [CrossRef]

30. Huang, J.; Pan, X.; Guo, X.; Li, G. Impacts of air pollution wave on years of life lost: A crucial way to communicate the health risks of air pollution to the public. Environ. Int. 2018, 113, 42-49. [CrossRef]

31. Brodny, J.; Tutak, M. Analysis of the diversity in emissions of selected gaseous and particulate pollutants in the European Union countries. J. Environ. Manag. 2019, 231, 582-595. [CrossRef]

32. Stamatios, N.; Skordoulis, M.; Kyriakopoulos, G.; Arabatzis, G.; Chalikias, M.; Galatsidas, S.; Batzios, A.; Katsarou, A. Renewable Energy and Economic Growth: Evidence from European Countries. Sustainability 2018, 10, 2626. [CrossRef]

33. Bointner, R. Innovation in the energy sector: Lessons learnt from R\&D expenditures and patents in selected IEA countries. Energy Policy 2014, 73, 733-747.

34. Boons, F.; Montalvo, C.; Quist, J.; Wagner, M. Sustainable innovation, business models and economic performance: An overview. J. Clean. Prod. 2013, 45, 1-8. [CrossRef]

35. Reiff, M.; Ivanicova, Z.; Surmanova, K. Cluster analysis of selected world development indicators in the fields of agriculture and the food industry in European Union countries. Agric. Econ. Czech 2018, 64, 197-205. [CrossRef]

36. Giannakis, A.; Bruggeman, E. The highly variable economic performance of European agriculture. Land Use Policy 2015, 45, 26-35. [CrossRef] 
37. Szabo, L'; Grznár, M. Agriculture in the EU and position of the Slovak Republic. Agric. Econ. Czech. 2015, 61, 493-501. [CrossRef]

38. Dos Santos, M.L. Segmenting farms in the European Union. Agric. Econ. Czech. 2013, 59, 49-57. [CrossRef]

39. Casini, M.; Bastianoni, S.; Gagliardi, F.; Gigliotti, M.; Riccaboni, A.; Betti, G. Sustainable Development Goals Indicators: A Methodological Proposal for a Multidimensional Fuzzy Index in the Mediterranean Area. Sustainability 2019, 11, 1198. [CrossRef]

40. Proksch, D.; Busch-Casler, J.; Haberstroh, M.M.; Pinkwart, A. National health innovation systems: Clustering the OECD countries by innovative output in healthcare using a multi indicator approach. Res. Policy 2019, 48, 169-179. [CrossRef]

41. Reibling, N. Healthcare systems in Europe: Towards an incorporation of patient access. J. Eur. Soc. Policy 2010, 20, 5-18. [CrossRef]

42. Wendt, C. Mapping European healthcare systems: A comparative analysis of financing, service provision and access to healthcare. J. Eur. Soc. Policy 2009, 19, 432-445. [CrossRef]

43. Hair, J.F., Jr.; Black, W.C.; Babin, B.J.; Anderson, R.E. Cluster Analysis. In Multivariate Data Analysis, 7th ed.; Prentice-Hall: Upper Saddle River, NJ, USA, 2010; pp. 415-475, ISBN 978-0138132637.

44. Kovačić, Z. Analiza grupisanja. In Multivarijaciona Analiza; Ekonomski fakultet Univerziteta u Beogradu: Belgrade, Serbia, 1994; pp. 255-293.

45. Ward, J.H., Jr. Hierarchical grouping to optimize an objective function. J. Am. Stat. Assoc. 1963, 58, $236-244$. [CrossRef]

46. Radojičić, Z.; Išljamović, S.; Petrović, N.; Jeremić, V. A novel approach to evaluating sustainable development. Probl. Ekorozw. Probl. Sustain. Dev. 2012, 7, 81-85.

47. Alestalo, M.; Hort, S.E.O.; Kuhnle, S. The Nordic Model: Conditions, Origins, Outcomes, Lessons. 2009. Available online: http://edoc.vifapol.de/opus/volltexte/2013/4255/pdf/41.pdf (accessed on 24 June 2019).

48. Hartmann-Hirsch, C. The State of the Luxembourg's Welfare State: The Effects of the Crisis on a Corporatist Model Shifting to a Universalistic Model. CEPS/INSTEAD Working Papers. 2010. Available online: http://www.statistiques.public.lu/catalogue-publications/working-papers-CEPS/2010/44-2010.pdf (accessed on 24 March 2016).

49. Djuran, J.; Golušin, M.; Munitlak, I.O.; Jovanović, L.; Andrejević, A. Renewable energy and socio-economic development in the European Union. Probl. Ekorozw. 2013, 8, 105-114.

50. Koster, F. Economic openness and welfare state attitudes: A multilevel study across 67 countries. Int. J. Soc.Welf. 2013, 21, 115-126. [CrossRef]

51. Megyesiova, S.; Lieskovska, V. Analysis of the Sustainable Development Indicators in the OECD Countries. Sustainability 2018, 10, 4554. [CrossRef]

52. Huttmanová, E. Sustainable Development and Sustainability Management in the European Union Countries. Eur. J. Sustain. Dev. 2016, 5, 475-482. [CrossRef]

(C) 2019 by the authors. Licensee MDPI, Basel, Switzerland. This article is an open access article distributed under the terms and conditions of the Creative Commons Attribution (CC BY) license (http://creativecommons.org/licenses/by/4.0/). 